\title{
Qualitative framing analysis on women's issues: the case study of the Hindu
}

\begin{abstract}
The treatment given to women's issues in newspapers gained wide attention these days. The coverage of issues pertaining to women's rights and violations have attained a new significance in mainstream English dailies. In a male-dominated and patriarchal society, women deem fit to have been relegated to secondary positions both in professional and domestic surroundings. The newspaper readers judge the status of women in society through the words, facts, and materials incorporated by the newspapers. This paper is an attempt to qualitatively analyze the framing of news from a women's rights paradigm as covered by the newspapers under study. The framing analysis of the selected pieces of the news items covered by the identified newspaper shows that the press seems to have covered the issues related to women and atrocities meted against them, but the portrayal of women appears to have been sensational and captivating as a whole. The exploration of women's achievements in multiple fields viz. financial stability, women entrepreneurship, women's self-help groups, etc. need to be highlighted by the newspapers rather depicting them as a consumable object and showcasing their beauty rather professing their strength.
\end{abstract}

Volume 3 Issue 5 - 2019

\author{
Afaq Ahmad \\ Department of Journalism, Lovely Professional University, India
}

Correspondence: Afaq Ahmad, Department of Journalism, Lovely Professional University, Punjab-I 44 4I I, India, Emailafaqmasscom@gmail.com

Received: June 12, 2019 | Published: October 10, 2019

Keywords: women's rights, framing analysis, qualitative analysis, the hindu

\section{Introduction}

Every individual, as a human being, is entitled to certain rights that are not dependent on their sex, ethnicity, colour, race, language, age, religion, political or other beliefs, national or social origin, property, economic status, disability, birth or other factors. These individual human rights are inalienable in that they cannot be taken away, desecrated or given away.

On the contrary, the single most important obstacle to media freedom in India and elsewhere is the failure to recognize the role played by independent journalism in the creation, nourishment, and achievement of sustainable development goals (SDG).

As far as women's rights are concerned, awareness is the focal point to promote the rights of women. The citizens must be able to celebrate achievements and successes. Media have a role to play in reporting good examples of tolerance, peace, and respect for women's rights. Women in India continue to be underrepresented in news coverage and are often stereotypically portrayed.

Women in the news are mostly featured in stories about domestic violence, sexual harassment, rape, rape-cum-murder, dowry death than in stories about their professional abilities and expertise. Women in politics are similarly sidelined. Journalists often tend to focus on the love and affair angle of the professionally active women's life rather than her struggle or achievement to have become a successful woman in society. Women deem fit to be considered more for their beauty and glamour in Hindi film industry and sports rather than their strength, brilliance, and intelligence. Further, the political and economic success stories are predominantly covered about men, while women are supposed to be left into lurch when covering such stories by journalists in India.

In view of the fact that there are a revolutionary change and growth in every sphere of life and mainly in the communication and media world, media, today, plays a decisive role in the development of society. Thus, the role of media in the protection of women's rights cannot be ignored or minimized. Media is a communicator of the public. Today its role extends not only to giving facts as news but it also analyses and comments on the facts and thus shapes the views of the people. Today, the impact of media on society is beyond doubt and debate. Politically active women are often disparaged and stereotyped by the media. Therefore, an adequate, in-depth and quality coverage of women's issues need a phenomenal change and the victimhood of women need to be revamped in media reporting.

The media has been setting social, political economic and even cultural agenda for the nation. With the advent of satellite channels, its impact has become even sharper and deeper. With twenty-four hours news-channels, people cannot remain neutral to and unaffected by what the channels are serving day and night. It is, therefore, of paramount importance that the media plays an important and ethical role at all levels and in all parts of the country and the world.

Media can play a major role in protecting and promoting women's rights in the country. It can make people aware of the need to promote certain values in the cause of women's rights. As women seem to have been given short shrift in media, the inclusion of women's issues in the mainstream slot should be the minimum common agenda for the media. The media can perform this role in different ways. It can make people aware of women's rights, expose its violations and focus attention on people and areas in need of the protection of women's rights and pursue their case until they achieve them. Media can also give publicity to individuals and organizations, which are engaged in securing women's rights. This will encourage as well as motivate others to do similar work. Media can inform and educate the people of their rights and suggest ways and means by which they can solve their problems and thus empowering them to protect their rights. Since media plays the role of communication between the state and 
the public, it can also play an effective role in making the authorities aware of their duties towards recognizing and securing women's rights.

Media's role is reporting, analyzing and commenting these days. It faces a challenge in playing the role in protecting women's rights in the world. While playing this new role, there is a risk of its misuse. For that self-regulation is the need of the hour. Journalists should set 'Lakshman Rekha' while reporting women's rights violations. The main aim before the journalists should be to give facts but not in a manner and with the purpose to create sensation and to arouse the sentiments of the people. Projection and language should be decent and civilized while covering women's rights issues. Journalists should not add insult to inquiry while covering news on rape and sexual assault against women. Media should refrain from giving statements and pictures that are flaring. Since media is the mirror of the society, proper care should be taken while reporting women's issues, especially issues related to violence and sexual abuse against women, so that the mirror may not become hazy. ${ }^{1}$ While reporting women's violations, the media should not get influenced by authorities. It should look deep into the problem and provide solutions. Mere reporting of the facts is not enough; it should give reasons of the problem and the nature of the violations and then give solutions.

\section{Review of literature}

An attempt has been made in this section to review the available literature on women's rights with a view to examining the different standpoints and views adopted by various scholars and experts. Martin $^{2}$ examined the issues of sexual violence, domestic violence, and sex trafficking in media portrayals. The researcher employed content analysis technique on six film releases, two for each of the topics and reviewed the prevalence of myths, stereotypes, victim portrayal, perpetrator portrayal in each of the films. He found that the portrayal of myths categorically varied in each of the films. The most common themes kept in the movies was the ineptitude of the criminal justice system to successfully intervene and aid victims. Another commonly occurring theme was that victims must escape their abusers individually, without the aid of social services or the criminal justice system. Sanbonmatsu ${ }^{3}$ (n.d.) in the inventory and collected articles examined the length and breadth of sexist media coverage during the 2008 U.S presidential campaign of Democratic challenger Hillary Clinton and Republican vice presidential nominee Sarah Palin. The researcher got to know that it can potentially increase public skepticism about a woman's fitness to serve as President or Vice President of the United States. The media coverage of Clinton and Palin centered on common stereotypes of corporate women (e.g., "sex object" "mother" "pet/cheerleader" and "iron maiden"). In moving forward, Cardin and Winfrey suggest that the media and the campaigns of female presidential candidates must attack sexism early to deter its negative influence. Moreover, scholars must educate the public about the prevailing gender stereotypes that took place during the 2008 Presidential campaign if the United States is ever to elect a female President or Vice President.

Linström \& Marais ${ }^{4}$ made it clear that qualitative news frame analysis can be done to achieve various media research purposes. They asserted that news frame analysis poses pertinent questions to those involved in the manufacturing and dissemination of news. The article is aimed at providing a step in this direction by attempting to provide a methodology for conducting a basic qualitative news frame analysis. In this context, the researchers mentioned various framing devices viz. written/grammatical and technical devices like elements of news writing, layout, visuals, etc. to achieve better results while conducting qualitative analysis in the field of journalism. Russo \& Pirlott ${ }^{5}$ highlighted new conceptualizations, methodological issues, and pertinent findings related to gender-based violence against women. The researchers identified cultural factors through media images that may increase women's risk for violence, and profiles a host of negative physical, mental, and behavioral health outcomes associated with victimization including unwanted pregnancy and abortion. They further noted that gender-based violence takes multiple forms and is rooted in patriarchal social structures and cultural roles of women and men, and is reinforced by media images.

\section{Importance of the study}

i. Today, due to the globalization of services, information, and labour - the media holds a powerful and robust role in communication.

ii. In the arena of communication, it is journalists who serve as the main actors in reporting the world's events and conveying valuable information pertaining to women's rights.

iii. Journalists hold the power to determine what news is and to construct stories and select words in ways that affect women's prestige.

iv. The news carries the ability to inform the public, to connect remote worlds, and to shape an individual's knowledge and understanding of the world s/he lives in. The content of the news has the opportunity to increase public awareness, to educate the public on their rights, and, above all, to help in monitoring women's rights.

v. Any discussion about how the media communicate women's rights, or how different players use the media as a vehicle, requires an examination of what information the media pick up and how it is treated.

vi. Through bringing together multiple perspectives by conducting qualitative framing analysis, it can create the potential for a more knowledgeable, well-rounded and aware public. This increased awareness can lead to a stronger civil society and a more active population.

\section{Objectives of the study}

i. To collect news contents, explore headlines and interpret the selected data for qualitative analysis;

ii. To evaluate news media reporting on women's rights issues by applying qualitative framing analysis;

iii. To conduct an in-depth analysis of the impact laid down by media and mainstream English National daily on the society and government as a whole in curbing women's rights violations and evoking such issues;

iv. To find out the media's capacity to provide accurate, reliable and timely information on women's rights issues are at the heart of this research work;

v. To examine the process of reporting on women's rights news by mainstream National English daily;

vi. To inspect print media reporting on portrayal of women - beauty versus strength 


\section{Hypotheses}

i. The mainstream National English daily generally covers news related to women by mixing sensational angle in it and presenting women as a consumable object.

ii. The framing of news on women is stereotyped and patriarchal rather than professionally sound and positively engrossing.

iii. The portrayal of women in print media sensationalize the issues rather than giving procedural coverage to them.

iv. The newspaper prioritizes women's issues in accordance with their specific agenda.

$\mathrm{v}$. The tonality of new coverage in print media present women as a product rather than a human being.

\section{Research methodology}

The methodology adopted in the study is the qualitative framing analysis and the universe or population is the news published in the mainstream National English daily depicting women's rights issues and its violations occurred between $01^{\text {st }}$ January to $31^{\text {st }}$ May 2017.

The qualitative analysis of news stories lends credibility to the cognitive thoughts for a piece of writing in the newspaper. The signifying elements of the newspaper and the meanings interpreted by the readers within the story may differ and the job of the researcher is to connect between the semantic differences of the news story and interpretation of the reader to produce qualitative results of the news story.

To a greater extent, the principal objective of carrying out the qualitative analysis was to find out this information - the tone and style of reporting of The Hindu while covering women's issues and the frames incorporated by the paper to cover such issues.

\section{Qualitative framing analysis of the selected news items published in the hindu}

Keeping in view the qualitative portrayal of news stories related to women's rights, the news stories published in mainstream English dailies will be critically examined to assess the kind of treatment would be given to women's rights issues.

Bengaluru; night of horror: This editorial was published on 5 January 2017 in The Hindu containing victim frame. The headline itself manifests that 'mass molestation' of a girl on new year's event kept the country's glory in dark for a while. The mass gathering of the revelers made several attempts to sexually abuse a girl during new year's celebrations at Bengaluru. Likewise, another girl who was on her way to her home had been molested on the streets. By including these two stories from women's point of view portrays paper's positive slant towards women. On the contrary, Karnataka Home Minister G. Parameshwara blamed the western culture proclaiming that women attract to be molested and sexually abused by cladding themselves in western attire which shows the minister's narrow-minded thoughts toward women. On the other hand, the paper has stood firmly keeping in mind its national repute and socialistic approach. The newspaper also focused on the existing and amended laws to curb sexual violence and cited that the Criminal Law (Amendment) Act, 2013 passed over national outrage over the Delhi gang rape of December 16, 2012, had sought to bring clarity to the continuum of sexual offences and to simplify procedures for women to bring them to the attention of police. The movement of women during the night or mid at night has been becoming a scourge and when a lawmaker publicly announces that wearing western clothes will provoke molestation in society, there is a lot to be done for the safety and security of women in the country.

Jharkhand university VC accused of sexual harassment: The news item was covered by The Hindu on 13 May 2017 encompassing oppressor frame. This was a six-column story on sexual harassment against women. A Professor who belongs from a Scheduled Tribe community of Central University of Jharkhand (CUJ) accused the Vice-Chancellor of molesting her and she had lodged an FIR under the Scheduled Castes and Scheduled Tribes (Prevention of Atrocities) Act, 1989, along with Sections 354D (stalking a woman), 120B (criminal conspiracy) and 509 (word, gesture or act intended to insult the modesty of a woman). The woman Professor also blamed in her written complaint that VC obstructed her research work by deliberately delaying due processes concerning with her research proposals. The university registrar, on behalf of the vice-chancellor, denied all the allegations made by the ST woman Professor and termed it as "baseless." The reporter did not bother to inspect this event-based story and merely took inputs form her corresponding colleague. Though the reporter tried to include the statements from both sides, the victim as well as oppressor, but the accuracy of the story prima facie lacks fairness as the reporter did not make a ground reporting of the incident.

Former Maoist's daughter to represent India in volleyball: This is a by-line news story covered appeared in The Hindu on 17 May 2017. The story contains three columns on women empowerment. A 15-year-old daughter of an erstwhile Maoist had been selected to represent the country in an international volleyball tournament held in China. Shireesa, the daughter of Chelamma Karami, a former Maoist cadre in Malkangiri district in Odisha, was selected for the under-18 national volleyball team. Shireesa attributed all credit to her mother for such a glaring achievement. Now, Shireesa is considered as the flagbearer of change for the entire region as in spite of belonging from a former Maoist's family she surpassed the societal hurdles to achieve her cherished goal. This is a positive news item covered by the paper which encompasses a pragmatic frame. But, the reporter made contact on phone while reporting the story and did not touch the place to feel the pulse of the news. Therefore, the ground reporting might have put some more pertinent facts than it explored (Table 1).

Table I Selected News Stories for Qualitative Framing Analysis on Women by the Hindu in 2017

\begin{tabular}{|c|c|c|c|c|c|c|}
\hline $\begin{array}{l}\text { S. } \\
\text { no. }\end{array}$ & Headline & $\begin{array}{l}\text { Datel } \\
\text { Page }\end{array}$ & Column & $\begin{array}{l}\text { Human } \\
\text { rights issue }\end{array}$ & $\begin{array}{l}\text { Content } \\
\text { category }\end{array}$ & Frame \\
\hline I & $\begin{array}{l}\text { Bengaluru; } \\
\text { night of } \\
\text { horror }\end{array}$ & $\begin{array}{l}5-J a n- \\
10\end{array}$ & 1 & $\begin{array}{l}\text { Sexual } \\
\text { Violence }\end{array}$ & Editorial & Victim \\
\hline 2 & $\begin{array}{l}\text { Jharkhand } \\
\text { university } \\
\text { VC accused } \\
\text { of sexual } \\
\text { harassment }\end{array}$ & $\begin{array}{l}13 \\
\text { May/06 }\end{array}$ & 6 & $\begin{array}{l}\text { Sexual } \\
\text { Violence }\end{array}$ & News & Oppressor \\
\hline 3 & $\begin{array}{l}\text { Former } \\
\text { Maoist's } \\
\text { daughter to } \\
\text { represent } \\
\text { India in } \\
\text { volleyball }\end{array}$ & $\begin{array}{l}17 \\
\text { May/6 }\end{array}$ & 3 & $\begin{array}{l}\text { Women's } \\
\text { Empowerment }\end{array}$ & News & Pragmatic \\
\hline
\end{tabular}




\section{Findings \& suggestions}

i. The editorial policy of The Hindu had been remained intact in terms of evaluating each and every angle of the incident, event or happenings pertaining to molestation against women.

ii. The achievement of a female teenager in the field of sports belonging from distant and segregated part of the country had been minutely highlighted by the paper. The performance and success stories of such girls should be captured through ground reporting instead of telephonic communication.

iii. News related to the molestation and harassment against women found more prominence compared to other women's rights issues. Therefore, the procedural coverage of their professional heights and achievements in sports, entrepreneurship, business, and other sectors is required to be covered on certain intervals.

iv. The issues related to trafficking in women and dowry death had not been on the news agenda in the selected newspaper under study.

v. The Hindu downplayed sensationalist approach while covering stories related to sexual violence. On the negative side, the paper tried to sensationalise some of the stories on women for increasing its readership in a commercially driven media environment.

vi. The results had demonstrated that the selected newspaper covered slightly differed news stories and framed such stories in accordance with the paper's ideological slanting.

vii. As the paper is popular for encompassing equal inclination for all the communities beyond any caste, creed, group or language, investigative coverage on women's rights violations is required to be on the agenda of the newspaper under study.

\section{Suggestions for further research}

The study of qualitative framing analysis of The Hindu may benefit governmental organizations and authorities to understand the ideology of the newspaper in relation to women's issues. The coverage of women's issues by the newspaper will provide ingredient to competent authorities to acknowledge the issues of women which may pave the way to stitch up policies for the uplift of women. Further, the mainstream English newspapers are considered as the agenda-setter for women's rights issues, the government officials who are thought to be the proponent of several developmental schemes essentially read English newspapers. Therefore, the comparative analysis of the mainstream English dailies may also prove detrimental to acknowledge the policies and pattern of the newspapers to cover issues related to women's rights and their infringements.

\section{Acknowledgments}

None.

\section{Conflicts of interest}

The author declares that there is no conflict of interest.

\section{Funding}

None.

\section{Appendix}

The news stories used for qualitative framing analysis

Bengaluru's night of horror. (2017, January 5). Sexual Violence, The Hindu, p. 10.

\section{Bengaluru's night of horror}

I

is being called a "mass molestation". With all the creepiness and collective menace that the phrase conveys, the sketchy facts of the events of New Year's-eve in downtown Bengaluru once again hold a mirror up to Indian society. Thousands of revellers had gathered in and around Mahatma Gandhi Road and Brigade Road to ring in 2017 , as is something of a tradition in the city. But, according to reports that subsequently emerged, a large number of women were sexually assaulted around midnight. While no complaint had been filed, Bengaluru police have taken up an investigation based on the reports of women being groped and physically attacked. Another incident, reportedly also of the early hours of January 1, has come graphically into the public domain, with CCTV footage showing a woman being grabbed as she makes her way home in a residential street before she pulls herself free and escapes. This is unconnected to the so-called "mass molestation", but reinforces the horror of the night in Bengaluru. In an aftermath that has echoed with Karnataka Home Minister G. Parameshwara's effort to blame the violence on "western culture", it is easy to understand why no women came forth, at least initially, to register an offence. All too depressingly and predictably, the Minister has closed the loop to show how state and society fail to ensure the safety of women.

Mr. Parameshwara's insinuation that for women to wear "western" dress and be out and about having a good time is to invite sexual harassment, ironically, explains the reluctance of women to register offences. For, to do so is to very often court an accusatory glare, and be made to answer why they were out in a lonely street, after dark, in a place teeming with "boys" - or put simply, why they did not know better. The Criminal Law (Amendment) Act, 2013, passed after national outrage over the Delhi gang rape of December 16, 2012, had sought to bring clarity to the continuum of sexual offences and to simplify procedures for women to bring them to the attention of the police. To truly convince women that the state is on the same page, every crime against a woman must be regarded as a horror. But without an administrative ethos that does not flip an accusation on a woman and instead asserts a woman's right to bodily integrity no matter where she is and what she is doing, no amount of law-making can significantly change things. This is the challenge before the Bengaluru police as they look for women to come forward and assist in the investigation.

Jharkhand university V-C accused of sexual harassment. (2017, May 13). Sexual Violence, The Hindu, P. 6.

Former Maoist's daughter to represent India in volleyball. (2017, May 17). Women Empowerment, The Hindu, p. 6. 


\section{Jharkhand university V-C accused of sexual harassment}

\begin{tabular}{|c|c|c|c|c|c|}
\hline $\begin{array}{l}\text { STAFF REPORTER } \\
\text { KOLKATA } \\
\text { A Central University of } \\
\text { Jharkhand (CUJ) professor } \\
\text { has accused the Vice-Chan- } \\
\text { cellor of "sexual } \\
\text { harassment". } \\
\text { In a first information re- } \\
\text { port lodged on May } 3 \text {, she } \\
\text { has accused the V-C of sexual } \\
\text { harassment, while four other } \\
\text { university officials, including } \\
\text { the Registrar, have been ac- } \\
\text { cused of working in collusion }\end{array}$ & $\begin{array}{l}\text { with the V.C. However, uni- } \\
\text { versity authorities have de- } \\
\text { scribed the allegations as } \\
\text { "baseless". } \\
\text { case lodged } \\
\text { "A case has been lodged } \\
\text { against the accused under } \\
\text { the Scheduled Castes and the } \\
\text { Scheduled Tribes (Preven- } \\
\text { tion of Atrocities) Act, 1989, } \\
\text { along with Sections 354D } \\
\text { [stalking a woman], 120 B } \\
\text { [criminal conspiracy] and }\end{array}$ & $\begin{array}{l}509 \text { [word, gesture or act in. } \\
\text { tended to insult the modesty } \\
\text { of a woman]," said Manju } \\
\text { Kujur, the officer in charge of } \\
\text { the SC/ST police station in } \\
\text { Ranchi. The Professor be- } \\
\text { longs to the Scheduled } \\
\text { Tribes community. } \\
\text { In the FIR, a copy of } \\
\text { which is with The Hindlu, she } \\
\text { has alleged that V-C Nand Ku- } \\
\text { mar Yadav 'Indu' started har- } \\
\text { assing her though "gesture } \\
\text { [behaviour] of sexual }\end{array}$ & $\begin{array}{l}\text { nature" since "their first offt: } \\
\text { cial meeting" in December } \\
2015 \text {. } \\
\text { Obstruct research work } \\
\text { She further alleged that not } \\
\text { only did he "unduly delay } \\
\text { and obstruct her research } \\
\text { and academic work, but also } \\
\text { called her frequently to talk } \\
\text { about his personal life and } \\
\text { relations". } \\
\text {-Despite the fact that no } \\
\text { one should enter a women's }\end{array}$ & $\begin{array}{l}\text { [department] room without } \\
\text { permission, Prof. Indu' } \\
\text { would enter our room [at the } \\
\text { unlversity] silently. Some- } \\
\text { times when I would be busy } \\
\text { working, I would be taken } \\
\text { aback to suddenly find him } \\
\text { standing very close to my } \\
\text { chair and watching me } \\
\text { work," she has stated in the } \\
\text { FIR. } \\
\text { She has also accused the } \\
\text { v.Cof speaking to her in an } \\
\text { "inappropriate manner" in }\end{array}$ & $\begin{array}{l}\text { front of other faculty } \\
\text { members. } \\
\text { When The Hindu tried to } \\
\text { contact the V-C, Registrar } \\
\text { Ratan Kumar Dey answered } \\
\text { the call and said that "the } \\
\text { V-C wasn't available for com- } \\
\text { ments". Describing the Pro- } \\
\text { fessor's allegations as "base- } \\
\text { less", Mr. Dey added that the } \\
\text { V.C has "already given his } \\
\text { views in a press conference." } \\
\text { (With inpurs from Manob } \\
\text { Choudhury in Ramcht) }\end{array}$ \\
\hline
\end{tabular}

\section{Former Maoist's daughter to represent India in volleyball}

\section{5-year-old selected for under-18 national volleyball team}

\begin{abstract}
SIB KUMAR DAS
BERHAMPUR

The 15-year-old daughter of a former Maoist has been selected to represent the country in an international volleyball tournament to be held in China in August.

Shireesa, the daughter of Chelamma Karami, a former Maoist cadre of Malkangiri district in Odisha, was selected for the under-18 national volleyball team following her outstanding performance at the junior championship camp held at Ernakulum in Kerala from April 19 to 24 .
\end{abstract}

\section{All credit to mother}

Speaking to The Hindu over phone from Malkangiri, Shireesa credited her success to her mother. "I faintly remember my father, whom I had seen only once several years ago. My mother took the responsibility of raising me and my sister," she said.

At one time, Chelamma was the most wanted naxalite in Odisha and adjoining Andhra Pradesh. Disillusioned with the violent activities of Maoists, she left the organisation in 1994. After surrendering she spent al-

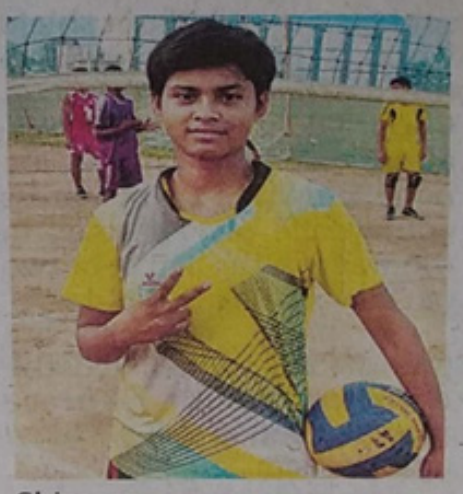

Shireesa

most six years in prison and was released in 2000. She then took up the job of a cook at the Government (SSD) Girls' High School and began a new life. Her priority was to provide proper education to her daughters.

Chelamma's efforts are now bearing fruit. Apart from excelling in sports, Shireesa is also performing well in studies.

She secured $73.28 \%$ marks in the Class $\mathrm{X}$ board examinations this year.

Shireesa's success in volleyball is also due to the determination and perseverance of her coach, Gyanendra Prasad Badoi, the District Sports Office Malkangiri. According to Badoi, he shares a fath daughter relationship * Shireesa and she calls 'bapa' (father). Mr. Bado trained volleyball coa spotted Shireesa in $2013 \mathrm{~d}$ ing a visit to her school. was among the 80 girls the district selected for av leyball coaching camp. Af a year, the camp was dis tinued, but Mr. Badoi con ued to coach her.

'Flag bearers of changt "I made arrangements that she could come Malkangiri from Kalim during holidays and w ends for coaching. Now support from the adm tration, she will be takin mission in Malkangiri lege and continue volleyball practise," Badoi said.

On Wednesday, Malkangiri district p will honour Shireesa an mother. "They are st flag bearers of a change th is taking place in this gion," said Malkangiri Supe intendent of Mitrabhanu Mohapatra. 


\section{References}

1. Mathew M. Media self-regulation in India: A critical analysis. ILI Law Review. 2016;25-37.

2. Martin KA. Domestic violence, sexual assault, and sex trafficking in the media: A content analysis (Master's Dissertation). Department of Sociology, Anthropology, and Criminology, Eastern Michigan University, Ypsilanti, Michigan. 2013
3. Sanbonmatsu K. Media coverage of women candidates. Political parity Center for American Women and Politics, Rutgers University. 2017.

4. Linström M, Marais W. Qualitative news frame analysis: A methodology. Communitas. 2012;17:21-38.

5. Russo NF, Pirlott A. Gender-based violence concepts, methods, and findings. New York Academy of Sciences. 2006;1087:178-205. 